\title{
Postpartum atypical haemolytic uremic syndrome: a rare case report
}

\author{
Neha Khatod $^{1}$, Shubhra Mukharjee ${ }^{1 *}$, Vijay Malviya ${ }^{2}$
}

${ }^{1}$ Department of Obstetrics and Gynecology, ${ }^{2}$ Department of Medicine, ESIC Model Hospital, Madhya Pradesh, India

Received: 16 July 2020

Revised: 04 October 2020

Accepted: 05 October 2020

\section{*Correspondence:}

Dr. Shubhra Mukherjee,

E-mail: shubhra15579@gmail.com

Copyright: (c) the author(s), publisher and licensee Medip Academy. This is an open-access article distributed under the terms of the Creative Commons Attribution Non-Commercial License, which permits unrestricted non-commercial use, distribution, and reproduction in any medium, provided the original work is properly cited.

\begin{abstract}
Hemolytic uremic syndrome (HUS) is characterized by triad of microangiopathic hemolytic anaemia, Thrombocytopenia and Acute renal failure. Genetically predisposed women develop HUS and may be triggered by pregnancy. The diagnosis is challenging due to overlapping clinical features of other diseases in pregnancy. The longterm prognosis is guarded. We are presenting a case of a young primigravida who underwent emergency lower (uterine) segment caesarean section (LSCS). She developed progressive anaemia, thrombocytopenia and renal failure postoperatively. Aggressive management with plasmapheresis, blood transfusions and hemodialysis saved her life. She is currently in remission.
\end{abstract}

Keywords: Hemolytic uremic syndrome, Plasmapheresis, Fresh frozen plasma, Acute renal failure

\section{INTRODUCTION}

Atypical haemolytic uremic syndrome is a rare condition characterized by micro angiopathic haemolytic anaemia, thrombocytopenia and acute kidney injury. ${ }^{1}$ It is a disastrous haemolytic disease characterized by diffuse endothelial damage and platelet consumption. It affects one out of every 25,000 pregnancies. ${ }^{2}$ Most cases of pregnancy associated HUS occur during post-partum period. Early diagnosis may be challenging during the puerperium. Correct diagnosis and timely management are crucial to improve outcome.

\section{CASE REPORT}

A 22-year-old primigravida with term pregnancy, reported to the labour room in early labour in emergency hours. In view of non-reassuring CTG and contracted pelvis on pelvic examination, a decision of emergency lower (uterine) segment caesarean section (LSCS) was taken. Her preoperative investigations were normal.

ower (uterine) segment caesarean section LSCS was done smoothly and patient was shifted to post-operative ward.
On post-operative (post op) day 2 the urine output decreased steadily. Investigations revealed haemoglobin 7(g\%) WBC 18000/per cubic $\mathrm{mm}$ and platelets $50,000 /$ per cubic $\mathrm{mm}$, blood urea was $80 \mathrm{mg} / \mathrm{dl}$, serum creatinine was $2.4 \mathrm{mg} / \mathrm{dl}$. A provisional diagnosis of sepsis was made. Higher antibiotics started, hydration maintained, urine output improved. On post op day 3 investigations revealed haemoglobin $6(\mathrm{~g} \%)$, WBC count 17,000 per cubic mm, platelet count 37000 per cubic mm, blood urea $90 \mathrm{mg} / \mathrm{dl}$, serum creatinine $4.1 \mathrm{mg} / \mathrm{dl}, 2$ units of fresh blood was transfused. Pelvic ultrasound was normal with no collection. Blood, urine and vaginal cultures were sent. Patient was shifted for dialysis at a higher centre. On post op day 4 patients haemoglobin was $3(\mathrm{~g} \%)$, platelet count was 22,000 per cubic $\mathrm{mm}$, serum creatinine $6.5 \mathrm{mg} / \mathrm{dl}$. Liver function revealed increase in indirect bilirubin with high LDH (4000 mg/dl).

In view of the triad of clinical features of haemolytic anaemia, Thrombocytopenia and acute renal failure in the absence of sepsis, diagnosis of atypical hemolytic uremic syndrome was made. Her complement level was low. Patient underwent 4 cycles of plasmapheresis and three 
cycles of haemodialysis. She received 4 units of packed cell transfusion and 20 units of fresh frozen plasma.

Patient started showing improvement steadily, the haemoglobin improved and renal function became better. She was discharged with near normal lab parameters (HB $9 \mathrm{~g}$, platelet count 2 lac/cumm, serum creatinine $1.4 \mathrm{mg} / \mathrm{dl})$. She is in sustained remission till date.

\section{DISCUSSION}

Pregnancy associated atypical HUS is a systemic disease associated with uncontrolled alternative complement pathway activation. Most cases of pregnancy-associated HUS occur during the postpartum period. Alexandra B et al found $76 \%$ cases presenting during post-partum period. ${ }^{3}$ Fakhouri et al observed $79 \%$ incidence in postpartum period. The diagnosis of postpartum atypical HUS can be challenging, as this condition mimics several other diseases that must be ruled out when making a diagnosis. The clinical features overlap with condition like HELLP syndrome, acute fatty liver of pregnancy, thrombotic thrombocytopenic purpura (TTP). ${ }^{2}$ The differentiating features are highlighted in (Table 1). Apart from the clinical features, complement assay is supportive of diagnosis. Genetic analysis reveals mutation in membrane cofactor protein (MFP), complement factor $\mathrm{H}$ $(\mathrm{CFH})$ and factor I (FI), as studied by Caprioli J et al. ${ }^{4}$

Owing to the devastating course of disease, starting plasmapheresis within 24 hours of diagnosis, even with a clinical impression of HUS is reasonable. Our patient responded well to prompt initiation of Plasmapheresis. Egerman RS et al reported 11 cases of pregnancy associated HUS emphasising improved survival with aggressive therapeutic plasmapheresis. ${ }^{5}$ Duration of plasmapheresis is individualized on the basis of patient's response. A multidisciplinary team consisting of Obs Gynae specialist, Intensivist, Nephrologist, Haematologist and Pathologists should be involved in the management.

Management includes plasmapheresis, high dose steroids, packed cell transfusions and complement inhibitors (Table 2).

Table 1: Clinical imitators of p-aHUS.

\begin{tabular}{|c|c|c|c|c|}
\hline & HELLP & AFLP & TTP & aHUS \\
\hline Time of onset & 3rd trimester & 3rd trimester & $\begin{array}{l}\text { 2nd and 3rd } \\
\text { trimesters }\end{array}$ & Postpartum \\
\hline Recovery after delivery & $1 \mathrm{wk}$ & $1-2 \mathrm{~d}$ & No recovery & No recovery \\
\hline $\begin{array}{l}\text { Primary/unique clinical } \\
\text { manifestation }\end{array}$ & $\begin{array}{l}\text { Hypertension and } \\
\text { proteinuria }\end{array}$ & $\begin{array}{l}\text { Nausea, } \\
\text { vomiting, malaise }\end{array}$ & $\begin{array}{l}\text { Neurological } \\
\text { symptoms }\end{array}$ & $\begin{array}{l}\text { Renal } \\
\text { involvement }\end{array}$ \\
\hline DIC (\%) & Less than 20 & $50-100$ & Rare & Rare \\
\hline Acute kidney injury & Mild/moderate & Moderate & Mild/moderate & severe \\
\hline \multicolumn{5}{|l|}{ Lab findings } \\
\hline Hemolytic anemia & + & $0 /+$ & ++ & + \\
\hline $\begin{array}{l}\text { Partial thromboplastin time } \\
\text { increase }\end{array}$ & $0 /+$ & + & 0 & 0 \\
\hline Hypoglycemia & 0 & + & 0 & 0 \\
\hline Thrombocytopenia $\left(<100,000 / \mathrm{mm}^{3}\right)$ & More than 20,000 & More than 50,000 & 20,000 or less & More than 20,000 \\
\hline LDH (IU/L) & 600 or more & Variable & More than 1,000 & More than 1,000 \\
\hline Elevated ammonia & $0 /+$ & + & 0 & 0 \\
\hline Elevated bilirubin & $0 /+$ & + & + & NA \\
\hline Liver transaminase increase & + & ++ & 0 & 0 \\
\hline vWF multimers & 0 & 0 & + & + \\
\hline ADAMTS13 $<10 \%$ & 0 & 0 & ++ & + \\
\hline \multicolumn{5}{|l|}{ Clinical signs/symptoms } \\
\hline Purpura & 0 & 0 & + & 0 \\
\hline Fever & 0 & 0 & + & 0 \\
\hline Neurological findings & 0 & 0 & + & 0 \\
\hline Hypertension & + & $0 /+$ & $0 /+$ & + \\
\hline Jaundice & $0 /+$ & ++ & $0 /+$ & $0 /+$ \\
\hline Nausea and vomiting & $0 /+$ & $0 /+$ & + & + \\
\hline Abdominal pain & $0 /+$ & $0 /+$ & + & + \\
\hline
\end{tabular}

(Abbreviations: ++ , always present; + , usually present; $0 /+$, occasionally present; 0 , absence; AFLP, acute fatty liver of pregnancy; paHUS, pregnancy-associated atypical haemolytic-uremic syndrome; DIC, disseminated intravascular coagulation; HELLP, haemolysis, elevated liver enzymes, and low platelet count; LDH, lactate dehydrogenase; NA, not available; TTP, thrombotic thrombocytopenic purpura). 
Table 2: Proposed initial management of atypical HUS.

Proposed initial management of atypical haemolyticuremic syndrome

Start plasma exchange ASAP (after obtaining all pertinent laboratories such as ADAMTS 13)

Avoid transfusion of platelets prior to central line placement

Consider high-dose steroids (prednisone $1 \mathrm{mg} / \mathrm{kg} / \mathrm{d}$ )

Start renal replacement therapy as needed for hyperkalaemia, pulmonary edema, metabolic acidosis, and uremia

Transfuse packed red blood cells as needed to keep haemoglobin level $>7 \mathrm{~g} / \mathrm{dL}$

If diagnosis of atypical HUS confirmed, consider prolonged therapy with complement inhibitors (eculizumab)

Abbreviation: HUS, haemolytic-uremic syndrome

Our patient had sustained remission with improvement of renal function and discontinuation of dialysis similar to the study by McCraeka et al. ${ }^{6}$ Recent evidence suggest that compliment inhibitors increase the platelet counts, improve renal function and decrease the need for renal replacement therapy.

However, its use is limited in India. A better understanding of complement dysregulation in pregnancy complication is essential to guide development of pharmacological agents to modulate this system. ${ }^{7}$

\section{CONCLUSION}

Early diagnosis of Atypical HUS in pregnancy is challenging as many clinical features overlap with other conditions of pregnancy. Early correct diagnosis and timely management may be lifesaving and multidisciplinary approach is beneficial in such patients.
Funding: No funding sources

Conflict of interest: None declared

Ethical approval: Not required

\section{REFERENCES}

1. Noris M, Remuzzi G. Atypical hemolytic-uremic syndrome. N Engl J Med. 2009;361(17):1676-87.

2. Saad AF, Roman J, Wyble A, Pacheco LD. Pregnancy-associated atypical hemolytic-uremic syndrome. Asia J Pharmaceut Report. 2016;6(1):e125.

3. Bruel A, Kavanagh D, Noris M, Delmas Y, Wong EK, Bresin E, et al. Hemolytic uremic syndrome in pregnancy and postpartum. Clinic J Americ Soc Nephrol. 2017;12(8):1237-47.

4. Caprioli J, Noris M, Brioschi S. Genetics of HUS: the impact of $\mathrm{MCP}, \mathrm{CFH}$, and IF mutations on clinical presentation, response to treatment, and outcome. Bloo. 2006;108(4):1267-79.

5. Egerman RS, Witlin AG. Thrombotic Thrombocytopenic Purpura and HUS in pregnancy: review of 11 cases AM J Obstet Gynecol 1996; 175:950.

6. Mc Craeka, Cines DB, Thrombotic Microangiopathy during pregnancy. Semin Hematol 1997;34:148.

7. Fakhouri F, Roumenina L, Provot F, Sallée M, Caillard S, Couzi L, et al. Pregnancy-associated hemolytic uremic syndrome revisited in the era of complement gene mutations. J Americ Soc Nephrol. 2010;21(5):859-67.

Cite this article as: Khatod N, Mukharjee S, Malviya V. Postpartum atypical haemolytic uremic syndrome: a rare case report. Int J Reprod Contracept Obstet Gynecol 2020;9:4710-2. 